\title{
How Climate Action at Regional Level Contributes to the Objectives of the UNFCCC: The APEC Case
}

\author{
Antonina Ivanova', Ana B. Cuevas Tello² \\ ${ }^{1}$ Academic Department of Economics, Universidad Autonoma de Baja California Sur, La Paz, Mexico \\ ${ }^{2}$ Academic Department of Pacific Studies, Universidad de Guadalajara, Guadalajara, Mexico \\ Email: antonina03@hotmail.com,anact@hotmail.com
}

How to cite this paper: Ivanova, A. and Tello, A.B.C. (2016) How Climate Action at Regional Level Contributes to the Objectives of the UNFCCC: The APEC Case. Modern Economy, 7, 1428-1443.

http://dx.doi.org/10.4236/me.2016.712131

Received: September 24, 2016

Accepted: November 5, 2016

Published: November 8, 2016

Copyright $\odot 2016$ by authors and Scientific Research Publishing Inc. This work is licensed under the Creative Commons Attribution International License (CC BY 4.0).

http://creativecommons.org/licenses/by/4.0/ c) (i) Open Access

\begin{abstract}
When APEC (Asia-Pacific Economic Cooperation) launched the Declaration on Climate Change, Energy Security and Clean Development in 2007 (better known as the Declaration of Sydney), environmental groups, civil society, experts and academics had recently celebrated two years of entry into force of Kyoto Protocol, which despite the slowness to achieve objectives kept hopes of real results; at the same time there were concerns that the proposal of APEC (with participation of the United States and Australia) would be a boycott of the Kyoto Protocol. This paper is arguing that the climate action within APEC is an important element to reinforce the international climate action on world level under the leadership of UNFCCC (United Nations Framework Convention on Climate Change). The analysis is focusing exclusively on common commitments assumed as members of APEC as regional body and not on the particular objectives of the member economies. Although it requires global commitment to address climate change, APEC has many resources to modify the process of global climate change significantly, this because besides emitting more than $60 \%$ of greenhouse gases (GHG), among its members are economies with a high degree of economic development (required for technological innovation), nations with the highest economic growth in recent decades (essential for poverty reduction and clean technology implementation) and international leaders with global influence (political hegemony: United States and China). Moreover, it is easier to agree among 21 economies than among the 200 nations of the world; but, if desired, any country can adhere to the objectives of APEC, since one of the characteristics of this forum is the open regionalism. This combination of elements makes APEC a force for success in the action against climate change in the world.
\end{abstract}

\section{Keywords}

Climate Change, UNFCCC, APEC, Regional Agreement, Climate Action 


\section{Introduction}

When APEC (Asia-Pacific Economic Cooperation) launched the Declaration on Climate Change, Energy Security and Clean Development in 2007 (better known as the Declaration of Sydney), environmental groups, civil society, experts and academics had recently celebrated two years of entry into force of Kyoto Protocol, which despite the slowness to achieve objectives kept hopes of real results; at the same time there were concerns that the proposal of APEC (with participation of the United States and Australia) would be a boycott of the Kyoto Protocol.

This paper is arguing that the climate action within APEC is an important element to reinforce the international climate action on world level under the leadership of UNFCCC. Although it requires global commitment to address climate change, APEC has many resources to modify the process of global climate change significantly, this because besides emitting more than $60 \%$ of GHG, among its members are economies with a high degree of economic development (required for technological innovation), nations with the highest economic growth in recent decades (essential for poverty reduction and for buying clean technology from developed countries) and international leaders with global influence (political hegemony: United States and the thriving economic power of China). Moreover, it is easier to agree among 21 economies than among the 200 nations of the world; but, if desired, any country can adhere to the objectives of APEC, since one of the characteristics of this forum is the open regionalism. This combination of elements makes APEC a force for success in the action against climate change in the world.

The paper analyzes firstly the APEC Sydney Declaration and compares it to the UNFCCC principles and main statements. Secondly, the specific climate action programs and instruments within the APEC region are presented, to finalize with some brief conclusions.

\section{UNFCCC and APEC's Sidney Declaration}

Climate change and it's impacts are of global concern; therefore, in the early nineties the international community began the construction of an international regime through the United Nations Framework Convention on Climate Change (UNFCCC), whose main objective was to stabilize "concentrations of greenhouse gases in the atmosphere at a level that prevents dangerous anthropogenic interference in the climate system. Such a level should be achieved within a timeframe sufficient to allow ecosystems to adapt naturally to climate change, to ensure that food production is not threatened and to enable economic development to proceed in a sustainable manner" [1]. As a result of the inception of this scheme, objectives, principles, commitments and internal procedures, that all signatory countries accepted and agreed to abide, were established.

The principles of the UNFCCC are: 1) protect the climate system for the benefit of present and future generations, on the basis of equity and in accordance with their common but differentiated responsibilities. Developed countries should take the lead in 
combating climate change, 2) take into account the specific needs and special circumstances of the Parties, such as developing countries, especially those that are particularly vulnerable to the adverse effects of climate change, 3) take precautionary measures to prevent and minimize the causes of climate change and its adverse effects, 4) parties are entitled to sustainable development and to promote it 5) cooperate in promoting the supportive and open international economic system that will lead to economic growth and sustainable development [1].

As seen, the principles of the UNFCCC are aimed broadly at recognizing the importance of climate change, working to prevent and reduce its impact (based on shared but differentiated responsibilities and the precautionary principle), promoting and cooperating in economic growth and sustainable development; while commitments are focused on the scope of the principles. In this sense, the Convention only encourages countries to take action, but does not elaborate binding mechanisms for their enforcement.

A few years later the member countries of the UNFCCC were aware that the established measures would not be enough to stop climate change; because of this, in 1995, during the first Conference of the Parties (COP1) in Berlin, the possibility to take firmer and more detailed commitments for developed countries was discussed. This was the situation in 1997, when, during the COP3, the Kyoto Protocol was adopted.

In the Kyoto Protocol quantitative objectives with specific time frames and legally binding were established. The compromise was that in the 2008-2012 period, industrialized countries (Annex I) would reduce the total of GHG emissions by at least $5.2 \%$ in relation to levels in 1990. Given that the GHG reduction process is a complex issue, as it requires changes in domestic economic activity, to achieve the objectives the establishment of flexible mechanisms was proposed, which were presented under four categories: 1) joint implementation ${ }^{1}$, 2) Clean Development Mechanism² $^{2}$, 3) emissions trading (recognized by their similarity to the futures market) ${ }^{3}$, 4) Adjustment Fund ${ }^{4}[1]$ and [2].

For the Kyoto Protocol to enter into force it was required that sufficient number of countries of the Annex I ratify the commitment of the Parties to the Convention, whose total emissions represented at least 55\% of carbon dioxide emissions in 1990. That's why after the ratification by Russia in 2004, by mid-February 2005 (8 years later) the Kyoto Protocol was launched with the absence of the United States and Australia. The USA, which at the time was the nation with the highest amount of carbon dioxide emissions, claiming damage to its domestic economy and exposing as unjust the fact of

\footnotetext{
${ }^{1}$ In which a developed country invests in other developed country, in a clean energy project. The investor gets certificates to reduce emissions at a lower price than it would have cost at the national level; while the host country benefits from investment and technology.

${ }^{2}$ It is when a developed country invests in clean development technology in a developing country. The decrease of pollution derivative from this investment is documented in a certificate that the company can exchange for GHG emission allowances in the country of origin.

${ }^{3}$ It is established so that countries that emit GHG below the limit imposed by the Protocol can sell their surplus emission allowances at those countries that exceed it.

${ }^{4}$ It facilitates the creation and deployment of techniques that can help to increase resilience after the impacts of climate change. That fund will be financed with a portion of proceeds from project activities of the Clean Development Mechanism.
} 
not forcing countries with high levels of pollution, as China and India, to reduce emissions, decided not to ratify the Protocol; while Australia remained in the position of the futility of its ratification when the main emitter of GHG had not.

When APEC first introduced the topic of climate change it conducted it in the discourse of the Environmental Vision Statement in 1994, but the impact on the economies of the region was no more than information and awareness. Since then APEC, in its annual statements, did not stop to mention sustainable development, clean production and the importance of natural and energy resources [3].

Meanwhile, in the international community, because of the environmental crisis that had been affecting the planet, together with the momentum generated by the Rio Summit, an individual and collective concern was developed, represented and promoted by NGOs, academics, international institutions and civil society, which invited the States to take action against environmental degradation and, specifically, climate change ${ }^{5}$. At the same time, in 2006 the Stern Review was published, which represented the most extensive review on the economic aspects of climate change.

Thus, when APEC launched the Declaration on Climate Change, Energy Security and Clean Development in 2007 (better known as the Declaration of Sydney), environmental groups, civil society, experts and academics had recently celebrated two years of entry into force of Kyoto Protocol, which despite the slowness to achieve objectives kept hopes of real results; while feared that the proposal of APEC (with participation of the United States and Australia) would be a boycott of the Kyoto Protocol [5]. At the same time, the publication of the Stern Review had aroused genuine concern in the States, as it was clear the convenience and efficiency for governments to take economic action against climate change in the present (preventive measures) than to have to take it later (in the short or medium term), when the costs would be higher and unavoidable.

It should be clarified at this point that according to McGee and Taplin [6], Sydney Declaration was not the first Asia Pacific mechanism which adds to the international climate change regime outside the guidelines of the United Nations, but from 2002 to 2007 the main defectors of the Kyoto Protocol (the United States and Australia) signed a number of bilateral agreements with various countries, and in 2006 entered into force the first multilateral agreement, better known as the Asia-Pacific Partnership for Clean Development and Climate (AP6); however, these were established under non-binding targets [6].

In this sense, the announcement of APEC about the consensus of strategies to address climate change was followed with particular attention, not only because the economic objective of APEC the inclusion of an environmental issue was a real challenge [7], but also for more specific reasons: first, the United States and Australia are APEC members; therefore, their apparent political will generated both positive (resume the commitment), and negative expectations (sabotage the Protocol). Second, the inclusion

${ }^{5}$ For further information, see González [4]. Educación ambiental: trayectoria, rasgos y escenarios. México: Plaza y Valdés. 
of China, country with major dispute within the Protocol increased the approval of the document. Third, the moderate success of the Kyoto Protocol placed special hopes on Sidney Declaration; Fourth, the pressure of the Stern Review; Fifth, the responsibility of APEC for emitting the greatest amount of GHG on the planet; and sixth, the fact of APEC consuming the greatest amount of fossil fuel energy.

It is important to note that prior to the Leaders' Summit 2007, APEC launched a document entitled The development costs of the Stern Review finding-implications for building consensus on global strategies for climate change, which was an analysis of the proposal of the Stern Review and offered evidence to justify the inclusion of the issue of climate change at the negotiating table that year. In the introduction to this paper was highlighted the need for commitment of APEC in climate action. Subsequently, the text states that no consensus on GHG reduction could be achieved, if the suggested strategies would restrict the economic development. This is based on the Stern report which states that if it is not acted in time overall costs of climate change would be equivalent to $5 \%$ of GDP now and in the future, but if there are included other non- economic issues such as health or the environment, the costs could reach 20\% [8]. Thus the APEC economies indicate that implementing climate action would be really expensive and that "a consensus can be built only if it allows each country to develop climate change strategies that do not interfere with economic goals" [9]. Finally, it was concluded that Stern Review exaggerates the benefits and overestimates the economic costs of implementing its recommendations [9]. Accordingly, the Stern Review gave the definitive guide to APEC economies, recognizing the need for commitment against climate change; however, it was made clear that APEC members are not willing to sacrifice economic growth.

The Declaration on Climate Change, Energy Security and Clean Development begins with the assertion that economic growth, energy security and climate change are fundamental and interlinked challenges for the APEC region. It mentions that the economic growth of APEC has reduced poverty and improved living standards; but that success is linked to energy supply that affects air quality and generates GHG emissions. Therefore, the introduction concludes with the commitment to ensure the energy needs and at the same time reduce GHG emissions [3]. The document of the Declaration of Sydney consists of three sections:

1) The section on Future International Action states that, based on the principles of the UNFCCC, an international agreement on climate change after 2012 must be fair and equitable:

a) Agreement that all economies contribute and share the overall goals in an equitable and effective manner, both economically and environmentally. b) Future climate change agreements need to reflect differences in economic and social conditions among economies and to be consistent with the effort of common but differentiated responsibilities. c) To ensure a global effort, flexible agreements that recognize different approaches and practical actions relevant to climate change are supported. d) Fossil fuels will continue to play an important role in the region and in the global energy needs. 
Cooperation, including collaborative research, development, deployment and transfer of technology of low and zero emissions for clean use, especially carbon, will be essential. e) Sustainable forest management and land use practices play a key role in the carbon cycle and are needed to take measures subsequent to the international climate change agreement in 2012. f) In pursuit of climate change and energy security policies, it must be avoided to introduce barriers to trade and investment. Trade openness, investment and environmental policies are crucial to the spread of low-emitting products, technology and best practices. g) Adaptation to the impacts of climate change is a priority for development strategies, which must be supported by the international community [3].

2) The support for an international agreement on climate change after 2012, roughly indicates a commitment of APEC with the overall objective of stabilizing GHG concentrations in the atmosphere at levels that will prevent dangers for humanity; noting that "the world needs to reduce, stop and reverse the growth of emissions of greenhouse gases" [3]. In this sense, APEC proposed setting the basis for an agreement subsequent to 2012, with the characteristics mentioned above.

3) Regarding APEC's action agenda, it assumes reducing energy intensity by at least 25 percent by 2030 (base 2005); advocates increasing forest cover in the region at least 20 million hectares of all types of forests by 2020; establishing a network of energy technology, and other for sustainable forest management within the region [3].

As shown, APEC is committed to green technology (energy efficiency) and forest management (forests are natural sinks for carbon dioxide); however, without changing the patterns of production and consumption that could threaten economic growth.

To understand better the proposal of APEC one must be familiar with the three approaches generated since the creation of the climate change regime: green governability, ecological modernization and civic environmentalism [10] and [12]. The first refers to the multilateral administration of environmental degradation, such as the UNFCCC and the Kyoto Protocol, in which emissions reduction is monitored from international-national level. The second relates to the proposal that environmental degradation can be disassociated from economic growth, and that capitalism and industrialization can be respectful to the environment based on green investment and trade regulation (AP6, Declaration of Sydney, Bilateral Treaties, Clean Development Mechanisms, etc.). And the third calls for a fundamental transformation of consumption patterns and existing institutions for a more eco-centric and equitable world order [6]. Thus, the issue of climate change entered the international agenda, according to different approaches that considered ecological awareness important, which led to the emergence of the climate regime by United Nation efforts (IPCC, UNFCCC, KP). When APEC joined the climate regime, it adopted the most points, with special emphasis on justice (that all countries must commit themselves to the fight against climate change in a fair and equitable manner, not only industrialized countries), and on continued economic development.

In this sense, it is clear in the Declaration of Sydney are considered the UNFCCC principles, as both recognize the importance of climate change and seek to address the 
issue through common but differentiated responsibilities. At the same time, they establish as priority cooperation and transfer of technology friendly to the environment, and consider among mitigation measures the conservation of forests and enhancement of the forest area. As for the differences, the values of the goals are pointed specifically (the ones of APEC are the farthest), as well as some specificities in terms of technology transfer and the forest management. However, these differences are, to some extent, understandable, since they represent the uniqueness of the region, while dates are traversed according to the needs of the development process of these economies.

In the Declaration of Sydney can be clearly noticed influence of the Stern Review, that is to say, knowing the figures-effects-costs-risks served as impetus to decide to take measures and strategies but, as they expressed it from the beginning, without risking economic growth, and with the proposal to allocate $5 \%$ of GDP to tackle climate change.

The most marked differences occur with the Kyoto Protocol, as, firstly, the proposed date for the achievement of the target and the base year for the reference change. Moreover, the flexible mechanisms are not mentioned and, most importantly, binding targets are left out. APEC members state being in favor of justice and equity in terms of responsibility beyond developed countries; and, in addition, intend to continue with the commitment subsequent to 2012 .

It is clear that the objectives of the Declaration of Sydney have a character of desirable and of not binding or mandatory. That is, it is betting that APEC economies, as responsible for a large proportion of greenhouse gas emissions, and acquainted with the risks by climate change impacts abide this commitment in an ethical, responsible, supportive manner, and even for convenience; that is to say, comply because it is considered a correct and necessary thing, but without reaching the limit of risking economic growth. This aroused criticism from environmentalists ${ }^{6}$, as they considered of little reliability and disappointing the proposal of the Declaration. Meanwhile, some opinions are that "political leaders seem to be very concerned about climate, when in reality they do very little" [11].

In addition, the resistance shown by some social groups to trust the results of the Sydney Declaration is understandable to certain extent, especially because the cooperation mechanism of APEC is non-binding (open dialogue and equal views). However, the members are reducing the greenhouse gases emissions, because the climate change impacts endanger the achievement of the social and economic objectives of APEC.

\section{Climate Action Programs and Instruments within APEC Region}

However, the Declaration of Sydney has not been the only proposal for APEC; in fact, the proposals issued after 2007 somehow are presented as practical and concrete steps to meet the objective of the Declaration; for example, the Program of Environmental

\footnotetext{
${ }^{6}$ Abigail Jabines (Greenpeace activist) stated that "without binding targets to reduce emissions of polluting gases, the Sydney Declaration is meaningless and irrelevant to this issue". She added, "If Howard and Bush wanted to make an effort in the climate issue they would ratify the Kyoto Protocol and adopt real solutions"; and concluded by accusing these two leaders of trying to sabotage the Kyoto Protocol [11].
} 
Goods and Services (EGS). Through this, APEC established strategies to reduce barriers for clean technology transfer among member countries. At the same time, another progress that occurred in this line was the signing in 2010, and subsequently ratification in 2011, of the Green Initiative, which aims to "create a favorable economic and political environment to facilitate green growth of Small and Medium Enterprises (SMEs) in the Asia Pacific region and to identify cooperative actions on the basis of voluntary reviews and exchange of politic experiences among members' economies" [12].

There is a close relationship between the Green Initiative and the green term used by APEC, which they adopt roughly as follows: Green technology, green growth and green products (goods and services). Items required for the Program of Environmental Goods and Services. Therefore, the readjustment that is performed on the Green Initiative is that this triad will be focused on SMEs. It is interesting to observe that there are countries where the Green Initiative started from the beginning of 2000, as in the case of Japan and Taiwan [13].

The fact that APEC decided, through government intervention, to support the Green Initiative in small, and medium-sized enterprises is justified by the following reasons: 1) SMEs are the largest employers of economically productive force, therefore are key actors in all economies, 2) in the transition towards a green development SMEs are important and necessary, 3) current environmental markets allow to improve the green SMEs, 4) green transition can be assisted by the support and intervention of national government, 5) SMEs would benefit the most from government intervention and support for the successful green transition, 6) because of the increasing interest of APEC members in environmental issues, especially climate change, 7) the rising prices of energy resources between 2005 and 2010 awoke the need for better and more efficient management of energy to generate savings and create security in this area, 8) the growing number of SMEs, specially manufacturing companies, and 9) the growing global demand of the international community for APEC (by their economic characteristics) to take effective action on climate change. It should be mentioned that the Green Initiative is based on the principle of voluntary review, non-mandatory [14].

The support for SMEs is a strategic plan, as it is evident that trade in environmental goods and services is taking a real importance in the international system. For example, the global trade in environmental products ${ }^{7}$ in 2010 reached a total of 871.5 billion dollars, accounting for $6 \%$ of world trade. In addition, from 2002 to 2010 , the average annual growth of this type of products was $12.8 \%$, slightly more than double of average total trade. Exports from APEC economies, in turn, accounted for 50.8\%, since they reached 443.5 billion dollars (imports showed a similar proportion). Similar trend occurs in the purchase and sale of environmentally-friendly technology [15]. At the same time, trade intra-APEC grew nearly $12 \%$, which reached the amount of 269.3 billion in 2010. Therefore, Asia Pacific, besides being the region that generates more trade at

\footnotetext{
${ }^{7}$ Assembled parts for multilayer floors, steam and water generators, auxiliary appliances for boilers, gas turbine parts, engine parts, industrial and laboratory furnaces, machinery for liquefying air and other gases, among others.
} 
global level, it is also the most dynamic in trading environmental friendly goods. What is interesting here is that APEC not only concentrates most of trade in EGS but it also presents higher growth rates than the rest of the goods traded. This is a too attractive market to be missed.

The 164 environmental goods traded in the world are classified in 12 categories: 1 ) control of air pollution; 2) heat and power generator; 3) clean technology, or of greater resource efficiency; 4) management of natural hazards; 5) management of solid and hazardous waste and recycling system; 6) sanitation of soil and water; 7) renewable energy plants; 8) management of water wastage and drinking water treatment; 9) environmentally preferable products based on the end-use and elimination characteristics; 10) protection of natural resources; 11) reduction of noise and vibrations, and 12) environmental monitoring, analysis and evaluation of equipment. Of these, the first four are the most demanded [15]. The relevance of these data is that the trade of EGS is not only important for developed economies but also for the developing.

Based on the importance of the green market and the role of APEC economies in it, this Forum in 2012 drew up a list of environmental goods, consisting of 54 items (solar panels, wind turbines, water heating system, etc.) that are classified into five categories ${ }^{8}$, as a strategy of trade openness and economic liberalization. The relevance of this list is that it will help to achieve the green growth agenda and at the same time it will serve to foster the market through trade liberalization and investment among members, as it is planned that the tariffs of these products will be reduced to five percent or less by 2015 [16]. This measure will be a major step because tariff reduction will decrease costs and better the accessibility to products, at the same time that increase in trade and job creation is expected. However, we must not forget the non-binding nature of the commitments of APEC.

Therefore, with green growth APEC hopes to achieve three objectives; first, increasing the use and trade of EGS; second, the energy efficiency and, third, reducing carbon dioxide emissions. It also seeks to fight against illegal logging, the promoting of vehicles of low carbon emission, the gradual elimination of inefficient subsidies and the remanufacturing of goods. Following the green growth, the dissemination of technology is expected [17].

There is evidence that APEC not only wants to generate less impact to the environment and enhance energy security, but also is competing and taking economic advantage in production and market of environmentally friendly products. This measure, although established under decisions of economic efficiency and trade growth, in the medium and long term will generate positive impacts on the environment and decrease GHG emissions.

Therefore, the green initiative proposed by APEC is in accordance with the principles of the UNFCCC, for technology transfer. This also meets one of the objectives

${ }^{8}$ Renewable technology and clean energy, technology for treatment and water wastage, control technology and air pollution, technology for the treatment of solid waste and hazards, and assessment teams and environmental monitoring. 
that the World Trade Organization established in the Doha Declaration in 2001, as it "urges Members to conduct negotiations on the reduction or, as appropriate, elimination of tariff and non-tariffs barriers to environmental goods and services" [18]. However, as presented by APEC, it is somewhat novel in the specific sense of focusing on the SMEs and fostering a potential market for green goods and services.

It is important to clarify that the Declaration of Sydney, the establishment of the Green Growth and the implementation of measures for Environmental Goods and Services, plus the implementation of green measures to SMEs, would not have been possible without the joint efforts and advice of the Energy Working Group of APEC (which consists of 4 expert groups: Clean Fossil Energy, Efficiency and Conservation of Energy, Data Analysis of Energy, and Renewable Energy Technology) and two more working groups, one responsible for biofuels and other focused on trade and investment of energy [19].

On the other hand, in 2008, members of the UNFCCC developed the Bali Action Plan, whose purpose was to seek international cooperation beyond 2012 (first deadline of the Kyoto Protocol, now extended to 2020) and reducing emissions in accordance with the provisions and principles of common but differentiated responsibilities and respective capabilities, and taking into account the socioeconomic conditions and other relevant factors (UNFCCC, 2008). It is important to note that this point was addressed first in the Declaration of Sydney and accepted by APEC.

In the Bali Action Plan mitigation and adaptation activities are highlighted. There is a call to intensify the measurable and verifiable mitigation actions appropriate for each country. These must be enabled by technology, financing and training. At the same time, it promotes "policies and incentives to reduce emissions generated by deforestation and forest degradation in developing countries; and the role of conservation, sustainable management of forests and enhancement of forest carbon stocks in developing countries". It also establishes the need to use markets "to improve the effectiveness of costs of mitigation measures and promote them, bearing in mind the different circumstances of developed and developing countries" (Idem).

In terms of adaptation, broadly speaking, there is a call for international cooperation to implement, urgently, adaptation measures, on the basis of vulnerability assessments [20]. There is also a call for the provision of mechanisms to remove barriers to the expansion of the work of technology development and the transfer of this, that at the same time promotes access to environmentally rational and affordable technologies (technology transfer). Finally, the importance of providing financial and investment resources, in order to support mitigation and adaptation actions, is highlighted [21].

As can be observed, the proposals of APEC are very similar to those presented in the report of Bali, rephrases some statements and the adaptation of commitments according to the characteristics of the economies of the region. The difference that is important to mention is that APEC does not dwell on the establishment of adaptation actions, since only mentions its importance.

The Copenhagen Agreement, in 2009, was quite controversial; however, it's signifi- 
cant element was the setting as a long-term goal limiting global temperature rise to no more than two degrees Celsius above pre-industrial levels [22]. What is of concern in this agreement is that neither actions nor proposals to achieve the objective were established.

In 2010 at the Conference of the Parties held in Cancun, Mexico, a common vision of long-term cooperation was established, where the following points were highlighted: 1) adaptation measures; 2) mitigation measures (country specific); 3 ) forest policies to reduce GHG emissions; therefore, preservation and conservation conditions of forests and jungles; 4) identification of opportunities for using markets, with the purpose of improving the cost effectiveness; 5) the issue of finance, technology and fostering of energy capacity, and, finally, the creation of a Green Fund [23].

The Green Fund was established in order to facilitate global efforts to achieve the goals set by the international community to effectively combat climate change. That is, through the fund it is aimed to provide a boost for the developing countries, so that, through projects, programs, measures and activities, they conduct toward economic development with low GHG emissions [24].

The interesting thing about COP 17, 2011, held at Durban, South Africa, was the planning of a process to develop a protocol legally binding and applicable to all Parties, called "Ad Hoc Working Group on the Durban Platform for Enhanced Action" [25]. This measure seems quite appropriate and necessary; however, deadlines are quite outdated (considering the urgency of environmental risks and in order to avoid the temperature rise to below $2^{\circ} \mathrm{C}$ for 2020), as they ask that this protocol is ready in 2015 to take effect in 2020.

Until the established in the COP 18, held in Doha, Qatar, which did not provide relevant elements or data, APEC is not above the maximum regulatory body of rules and principles of management of climate change, nor can determined that they complement each other; APEC simply enters the international climate change regime as a regional forum focused on trade openness and economic and investment liberalization.

It is clear that APEC measures seem more concrete than those presented by the UNFCCC. This has its roots in the fact that the Asia Pacific Forum, in addition to seek to reduce carbon dioxide emissions, because of the environmental risk for the region, is also looking to take advantage of the emerging green market and enjoy the benefit of innovation in alternative energy. The latter is very important because energy resources are the base of the production system, therefore represents power to the region [26]. Moreover, in pursuing to develop energy efficiency the economic opportunities of EGS trade are very important.

Facing climate change, it is clear that both UNFCCC and APEC have decided to cope by relying mainly on clean technology, alternative energy, reduction measures and recycling, plus innovation of green production, but so far none has made a call to decrease consumption, or to change the economic model, and it is clear that the of climate change will not be confronted at the expense of economic growth. Therefore, when APEC in 2010 chose green growth (promoting economic growth and development 
while ensuring that nature continues providing resources and environmental services) ${ }^{9}$, the aim was investment and innovation (along with the technology and clean energy resources), but not deceleration of economic growth.

Accordingly, in Rio +20 (held in 2012) reducing poverty is proposed as priority and, in the second place, making changes in consumption and production patterns; that confirms one more time that for international organizations the solution to poverty is the economic growth. In this sense, as said, changes in production and consumption (environmental goods and services) are suggested, but the reduction of growth is never considered [27].

In fact, UNFCCC and APEC, although not in a direct or formal way, support each other, as the first established norms, principles and agreements for countries for climate action; while the second, contributes in a personalized and regional way to the complex climate change regime.

Additionally, it is important to note the vulnerability within the APEC economies, not only in terms of fossil fuel dependence (80\%) and urgency of replacing it with renewable and alternative energy (plus innovation measures of energy efficiency), but also, this region has experienced more than $70 \%$ of natural disasters in the world as a result of climate change, which has represented economic losses of about 100 billion annually [28].

On the other hand, as a result of the frequent droughts, floods and hurricanes, primary sector producers that provide food (fishing and agriculture) have partnered with the private sector to ensure food security in the region and reduce the risk of climate change [28]. The business leaders of the food industry are cooperating to raise the resilience of the food producing sectors [29].

Regarding the latest agreement negotiated to stop the increase of temperature, the Paris Agreement, APEC adopted the following position "the world's largest regional economic group, is firmly committed to achieve a breakthrough at the Paris Climate Conference while ramping up efforts to build economic and technical capacity across their diverse Asia-Pacific economies to reduce emissions and mitigate the escalating threat of climate change" [28].

As so far analyzed, APEC (for reasons of economic expediency, political power, risk anticipation; and environmental concerns followed by the identification of an area of opportunity where it can generate great competitive advantages) has taken steps to curb emissions in an implied and tangible way. Although, according to Chen: "Green growth in APEC is formulated in a disorganized manner and does not function as a framework or strategy in which the problems and policies can be arranged for the realization of a sustainable APEC" [17]. The series of green growth measures has already begun to give results, as the business of environmental goods and services has been well accepted in the market [16], and the commerce of these products is growing at higher rates than global trade. This is expected to reduce GHG emissions in the coming years.

${ }^{9}$ For more information, see OECD (2011). Towards green growth. Summary for policy-makers. Available at: http://www.oecd.org/greengrowth/49709364.pdf. 


\section{Conclusions}

After more than two decades of integration within APEC, this is still ongoing. The economic and commercial purpose for which the Forum was created, and today finds considerable progress but it is far from its final goal. The approach of open trade and investment, plus economic liberalization that APEC resolved, have had a slow process for various reasons; one of the most important, in addition to the economic fluctuations and external policies, was the combination of the scope of the Bogor goals with the challenge of environmental degradation and specifically climate change.

It is clear that, in the face of climate change, APEC has strengths to cope in an outstanding way, since economic dynamism (innovation in clean technology and renewable energy) and the greatest forest cover of the planet give it great advantages. However, it also has weaknesses, given that it is the most vulnerable region to climate change impacts in the world. At the same time, the region experiences great dependence on energy resources, whose scarcity or high prices could affect economic development and population welfare. That's why APEC is interested in fostering energy efficiency and green technology, and thus has the opportunity to affront the climate change.

Since the beginning of the incorporation of proposals to tackle climate change, APEC has followed the guideline of the UNFCCC, since this is providing the international rules on the commitment. However, when the Declaration of Sydney was established, international community seriously focused on this member the main defectors of the Kyoto Protocol (the United States and Australia), because member economies as a whole generated over $60 \%$ of GHG emissions on the planet. In this sense, it is clear that what APEC does, or does not, will have significant positive or negative impacts on the climate change mitigation in the world.

APEC's proposal received also critics by some actors of the international community for perceiving it rather lax and little committed, especially for the lack of binding or mandatory targets. However, the work of APEC facing climate change has continued and in recent years is much more effective. Important step in this direction was avoiding tariff barriers to trade in environmental goods and services between member economies, and the EGS production and consumption have been fostered in most countries. Moreover, investment and green technology transfer are increasing in APEC region.

In 2010, APEC economies launched the Green Initiative, where the specific element to reduce emissions directly focuses on SMEs. This new initiative, although interesting and with great possibilities to work, is responding in first place to an economic interest and, secondly, ecological. In this sense, the fight against climate change is not through the reduction of production and consumption, but rather establishing production processes friendly to the environment, making energy resources more efficient and investing in clean technology (energy efficiency).

In this sense the regional efforts of APEC complement efficiently the efforts under-

${ }^{10}$ For more information, see OECD (2011). Towards green growth. Summary for policy-makers. Available at: http://www.oecd.org/greengrowth/49709364.pdf. 
taken by UNFCC on global level ${ }^{10}$ and the current position of APEC is consistent with the principles of the UNFCCC, for it also states that economic growth is the only way to resolve the problems of climate change and other global problems as poverty and the economic gap between the developed and developing countries.

With the establishment of the Sydney Declaration and the measures, strategies and subsequent agreements, APEC implicitly enters the complex international regime of climate change. Even when analyzing the gradual manner in which economies of this Forum are integrating environmental issues into their agenda, indirectly we realized that the complexity of this system responds to the complexity of climate change and the different ways of approaching it. Therefore, APEC determines its position based on the norms, principles and objectives of the UNFCCC, so there is congruence between the two organizations.

This paper presents the climate mitigation policies of APEC as a regional cooperation body, the specific policies of each APEC member economy, and the participation of the business and social sectors, could be recommended as further research on this topic.

APEC joins the regimen by its greatest strengths: the green economy and the market of environmental goods and services. Although the commitment is moral rather than binding targets, there are elements to indicate that APEC, in medium and long term will make an important contribution to climate change mitigation on world level.

\section{References}

[1] UNFCCC (1992) United Nations Framework Convention on Climate Change. http://unfccc.int/resource/docs/convkp/convsp.pdf

[2] UNFCCC (1998) Protocolo de Kyoto de la Convención Marco de Naciones Unidas para el Cambio Climático. http://unfccc.int/resource/docs/convkp/kpspan.pdf

[3] APEC (2007a) Leaders' Declaration. Sydney Declaration-Strengthening Our Community, Building a Sustainable Development. http://www.apec.org/Meeting-Papers/Leaders-Declarations/2007/2007 aelm.aspx

[4] González, E. (2007) Educación ambiental: Trayectoria, rasgos y escenarios. Plaza y Valdés, México.

[5] Cuevas, A. (2008) Las economías de APEC frente al cambio climático. México y la Cuenca del Pacífico, 11, 119-138.

http://www.mexicoylacuencadelpacifico.cucsh.udg.mx/sites/dfault/files/Las\%20econom\%C 3\%ADas\%20del\%20APEC\%20frente\%20al\%20cambio\%20clim\%C3\%A1tico.pdf

[6] McGee, J. and Taplin, R. (2009) The Role of the Asia Pacific Partnership in Discursive Contestation of the International Climate Regimen. Australia. International Environmental Agreements: Politics, Law and Economics, 9, 213-238. http://dx.doi.org/10.1007/s10784-009-9101-2

[7] APEC (2007b) Sydney APEC Leaders' Declaration on Climate Change, Energy Security and Clean Development.

http://www.apec.org/Meeting-Papers/Leaders-Declarations/2007/2007 aelm/aelm climatec hange.aspx

[8] Stern, N. (2006) Stern Review: The Economic of Climate Change. 
http://mudancasclimaticas.cptec.inpe.br/ rmclima/pdfs/destaques/sternreview report com plete.pdf

[9] The Australian APEC Study Centre (2007) The Development Cost of the Stern Review Finding-Implications for Building Consensus on Global Strategies for Climate Change. Monash University. http://www.itsglobal.net, http://www.apec.org.au/docs/07 SR.pdf

[10] APEC (2012a) The Green Initiative: Second Cycle of Daegu Initiative. Final Report. http://publications.apec.org/publication-detail.php?pub id=1302

[11] Emol. Mundo. (2007) Ambientalistas dicen que declaración de APEC sobre el clima es un gesto vacío.

http://www.emol.com/noticias/internacional/detalle/detallenoticias.asp?idnoticia=274933\#

[12] APEC (2012b) ANNEX C-APEC List of Environmental Goods.

http://apec.org/ /media/Files/LeadersDeclartions/2012/2012 AELM Declaration AnnexC. pdf

[13] Takahashi, K. (2012) Green Action Plan of Japan-APEC Green Initiative Workshop II. http://www.apec-smeic.org/workshop/?menu=2012

[14] APEC (2012d) Leaders' Declaration. Integrate to Grow, Innovate to Prosper. http://www.apec.org/Meeting-Papers/Leaders-Declarations/2012/2012 aelm.aspx

[15] Kuriyama, C. (2012) A Snapshot of Current Trade Trends in Potential Environmental Goods and Services. Policy Brief. 3. APEC Policy Support Unit, Singapore.

http://www.apec.org/About-Us/Policy-Support-Unit/ /media/0EBCBB67B44B4F06870EE4 DA72FD9029.ashx

[16] Tritasavil, T. (2012) On the APEC List of Environmental Goods. ISEAS, Singapore. http://www.iseas.edu.sg/images/pdf/ISEAS Perspective \%208Oct2012 Issue 6.pdf

[17] Chen, W. (2011) Strengthening Economy-Ecology Alignment and Incorporating Social Aspect for APEC Green Growth. 1-3. http://basc.berkeley.edu/ascc/papers/Chen Paper.pdf

[18] WTO (2013) Eliminación de los obstáculos al comercio de bienes y servicios ambientales. Programa de Doha para el Desarrollo.

http://www.wto.org/spanish/tratop s/envir s/envir neg serv s.htm

[19] APEC (2013a) Energy. http://www.apec.org/Home/Groups/SOM-Steering-Committee-on-Economic-and-Technic al-Cooperation/Working-Groups/Energy

[20] APEC (2013b) APEC Targets Reduced Disaster Risk. http://www.apec.org/Press/News-Releases/2013/0826 SDMOF.aspx

[21] UNFCCC (2008) Report of the Conference of the Parties on Its Thirteenth Session. Bali, 3-15 December 2007. http://unfccc.int/resource/docs/2007/cop13/eng/06a01.pdf

[22] UNFCCC (2010) Informe de la Conferencia de las Partes sobre su $15^{\circ}$ periodo de sesiones, celebrado en Copenhague del 7 al 19 de diciembre de 2009. http://unfccc.int/resource/docs/2009/cop15/spa/11a01s.pdf

[23] UNFCCC (2010) Cancun Climate Change Conference. http://unfccc.int/meetings/cancun nov 2010/meeting/6266.php

[24] UNFCCC (2011) Informe de la Conferencia de las Partes sobre su $16^{\circ}$ periodo de sesiones, celebrado en Cancún del 29 de noviembre al 10 de diciembre de 2010. http://unfccc.int/resource/docs/2010/cop16/spa/07a01s.pdf

[25] UNFCCC (2011) Durban Climate Change Conference. November/December 2011. http://unfccc.int/meetings/durban nov 2011/meeting/6245.php

[26] OECD/IEA (2011) Clean Energy Progress Report. OECD/IEA, France. 
http://www.iea.org/publications/freepublications/publication/CEM Progress Report.pdf

[27] UNCD (2012) Rio+20 United Nations Conferences on Sustainable Development. https://sustainabledevelopment.un.org/rio20

[28] APEC (2015) APEC Targets Climate Change Agreement, Capacity Building. http://www.apec.org/Press/News-Releases/2015/1203 COP21.aspx

[29] APEC (2016) APEC, Business Cultivate Climate Change-Proof Agriculture. http://www.apec.org/Press/News-Releases/2016/0511 PPFS Climate.aspx

\section{Submit or recommend next manuscript to SCIRP and we will provide best service} for you:

Accepting pre-submission inquiries through Email, Facebook, LinkedIn, Twitter, etc. A wide selection of journals (inclusive of 9 subjects, more than 200 journals)

Providing 24-hour high-quality service

User-friendly online submission system

Fair and swift peer-review system

Efficient typesetting and proofreading procedure

Display of the result of downloads and visits, as well as the number of cited articles Maximum dissemination of your research work

Submit your manuscript at: http://papersubmission.scirp.org/

Or contact me@scirp.org 